\title{
SOCIO ECONOMIC AND HEALTH CONDITION OF WOMEN AGRICULTURAL WORKERS IN THIRUVARUR DISTRICT, TAMIL NADU
}

\section{Dr. J. Raja Meenakshi*}

Dr. Sigamani, $\mathrm{P}$
ICSSR-Post Doctoral Fellow, Department of Social Work, Central University of Tamil Nadu, Thiruvarur-610 $005{ }^{*}$ Corresponding Author

Professor \& Head, Department of Social Work, Central University Of Tamil Nadu, Thiruvarur-610005.

ABSTRACT

Economic well being of India depends on the agricultural development since the livelihood of 60 per cent of the population is based on Agriculture and allied occupation. Women workers make a mammoth contribution in agricultural development but the socio economic condition of them is not quite appreciatable due to cultural and political reasons. Women face various issues at both work place and house for being women. This study has made an attempt to study the socio economic and health condition of women agricultural workers those who work in the field of land owners and get daily wages.This study was conducted in Srivanjiyam village of Thiruvarur district, Tamil Nadu.The result reveals that the 40.0 per cent of the respondents are illiterate and majority of them suffer with back pain, joint pain, leg pain and skin irritation.

KEYWORDS : Agriculture, Socio Economic, Health And Women

\section{INTRODUCTION:}

Rural women play a predominant role in agriculture as they get involved in the entire process like ploughing, sowing, weeding, applying fertilizers, harvesting, threshing, winnowing, packing, loading and related occupations like live stock management. Women does the work in the agricultural fields and also does all the domestic chores at house like cooking, cleaning, washing, taking care of children and elders etc.,In spite of enormous contribution women face innumerable issues and struggles both in the work place and in the house. Women are generally treated as secondary citizens in our nation and their work is not properly recognized. Agriculture, the single largest production endeavour in India contributing 25 per cent of GDP is increasingly becoming a female activity and it employs $4 / 5^{\text {th }}$ of all economically active women in the country. (Ghosh.M, 2014).Women workers in agriculture are at the lower level of the social order deprived of even the basic facilities like nutritional food, proper drinking water and health facilities. Women constitute about half of the world's population, their labour contributes to 60 per cent of the hours worked, contributing up to 30 per cent of official hours. Yet women receive only 10 per cent of the world's income and own less than one per cent of world's property (Qadeer, 1997).In relating to the health, the women workers face health issues due to occupational hazards that causes problems on General health ,Gynaecological and Menstrual Health, Psychological health, communicable and non communicable diseases. Health of women in agriculture is the baseline for the nation's development as they form the major portion of the potential human resource of the nation. Women in agriculture work to provide food for everyone and so their health is quite important to increase productivity and to enhance the life of others. The objective of this study is to find out the socio economic and health condition of the landless agricultural women workers in the Srivanjiyam village of Thiruvarur district - Tamil Nadu.

\section{REVIEW:}

Agriculture and women health is closely linked in many ways. The association between health and agriculture is bidirectional as agriculture influences health and health influences agriculture (Hawkes, C.2006). For the first time in the Indian history of planning, the eleventh Five Year documents women not only as equal citizens but as 'agents of sustained socio-economic growth and change' (Murty, 2008).Jayati Ghosh (2015) states 80 - 100 million Indian women have worked in agriculture over the past two decades, it is hard to find much evidence of this in policy making. The economy cannot grow sustainably without vibrant agriculture and the conditions of agriculture cannot improve without improving the conditions of women who work in it. Raja Meenakshi (2016) states that access to health care is very important as the health provides happiness and dignity to women. Health in the old age is the result of experiences of earlier years of life .The pattern of living which enhances health is formed early in life and is not easily altered. Mental Health is an indivisible part of general health and well being and as a concept reflects the equilibrium between the individual and environment in a broad sense. Discrimination, issues in relationship, physical health and poverty affects the mental health and there is a significant relationship between the age and health. Tarar MA et al (2016) in his study with 160 young and illiterate female farm workers 60 per cent of them have physical injuries, 93.8 per cent of respondents had pesticides related health troubles and 78.8 per cent had Asthma. It is also found that there is a highly significant association between usage of pesticide and health problems.

\section{METHODOLOGY: OBJECTIVE:}

- To study the socio economic condition of the Women Agricultural workers.

- To understand the General health issues faced by Women Agricultural workers.

\section{RESEARCH DESIGN:}

Study area is the Srivanjiyam village of Thiruvarur district which is predominantly an agricultural area located in the Cauvery Delta of Tamil Nadu. Srivanjiyam has the population of 2518 among 1268 are male and 1250 are female(Census, 2011). This village has been selected with consideration of the geographical location, total population, women population, primary and secondary occupation of the village, prevailing health facilities and accessibility to it, available social security and welfare measures in the village. Descriptive research design was adopted and the Landless Agricultural women labourers those who participated in the MGNREGA work from Octoberl- December 31, 2018 in the Srivanjiyam village of Thiruvarur District were taken as sample. Each worker has given a chance to participate in the study and the survey method was applied to collect the data. Interview schedule was administered with the sample of 125 respondents. In this study, Women agricultural workers are landless and work on the land of others for wages as coolie / 
daily wage labourers.

TABLE 1: SOCIO ECONOMIC CONDITION OF THE RESPO NDENTS

\begin{tabular}{|c|c|}
\hline Personal Details & Percentage \\
\hline \multicolumn{2}{|l|}{ Age } \\
\hline $20-30$ & 8 \\
\hline $31-40$ & 36 \\
\hline $41-50$ & 28 \\
\hline $51-60$ & 14 \\
\hline $61-70$ & 12 \\
\hline $71-80$ & 2 \\
\hline \multicolumn{2}{|l|}{ Marital status } \\
\hline Married & 75.2 \\
\hline Unmarried & 0.8 \\
\hline Widow & 24 \\
\hline \multicolumn{2}{|l|}{ Religion } \\
\hline Hindu & 99.2 \\
\hline Christian & 0.9 \\
\hline \multicolumn{2}{|l|}{ Caste } \\
\hline $\mathrm{BC}$ & 8.8 \\
\hline MBC & 2.4 \\
\hline $\mathrm{SC}$ & 88 \\
\hline ST & 0.8 \\
\hline \multicolumn{2}{|c|}{ Educational Qualification } \\
\hline Illiterate & 40.0 \\
\hline Primary school & 36.8 \\
\hline Middle school & 14.4 \\
\hline High school & 7.2 \\
\hline Higher Secondary & 0.8 \\
\hline Diploma & 0.8 \\
\hline \multicolumn{2}{|l|}{ Head of the Family } \\
\hline Myself & 23.2 \\
\hline Husband & 64.0 \\
\hline Father in Law & 2.4 \\
\hline Son & 9.6 \\
\hline Son in law & .8 \\
\hline \multicolumn{2}{|l|}{ Living Place } \\
\hline Own House & 97.6 \\
\hline Rental House & 2.4 \\
\hline \multicolumn{2}{|l|}{ Monthly Income } \\
\hline Rs.2000 -5000 & 56.8 \\
\hline Rs.5001- 10000 & 41.6 \\
\hline Rs.10001 - 15000 & 0.8 \\
\hline \multicolumn{2}{|l|}{ Outstanding Loan } \\
\hline Yes & 68.0 \\
\hline No & 32.0 \\
\hline \multicolumn{2}{|c|}{ Member of Self Help Group } \\
\hline Yes & 70.4 \\
\hline No & 29.6 \\
\hline
\end{tabular}

TABLE 2: GENERAL HEALTH CONDITION OF THE RESPO NDENTS

\begin{tabular}{|l|l|l|l|}
\hline General Health issues & Yes & No & Do not know \\
\hline Back pain & 88.8 & 12.0 & - \\
\hline Joint pain & 71.2 & 28.8 & - \\
\hline Leg pain & 69.6 & 30.4 & - \\
\hline Head ache & 37.6 & 62.4 & - \\
\hline Dust Allergy & 13.6 & 85.6 & 0.8 \\
\hline Swellings in Joints & 8.0 & 90.4 & 1.6 \\
\hline Fever & 8.8 & 90.4 & 0.8 \\
\hline Cold \& Cough & 27.2 & 71.2 & 1.6 \\
\hline General Malaise & 4.8 & 94.4 & 0.8 \\
\hline Chest pain & 10.4 & 86.4 & 3.2 \\
\hline Pain in shoulders & 26.4 & 72.8 & 0.8 \\
\hline Eye Problems & 15.2 & 84.8 & - \\
\hline Hearing problems & 3.2 & 95.2 & 1.6 \\
\hline
\end{tabular}

\begin{tabular}{|l|l|l|l|}
\hline Respiratory problems & 4.0 & 96.0 & - \\
\hline Throat Infection & 4.0 & 96.0 & - \\
\hline Skin Irritation & 52.0 & 46.4 & 1.6 \\
\hline Nervous problem & 4.8 & 93.6 & 1.6 \\
\hline Abdominal pain & 0.8 & 99.2 & - \\
\hline Urinal Infection & 16.0 & 83.2 & 0.8 \\
\hline Mouth Infection & 0.8 & 97.6 & 1.6 \\
\hline Cuts and wounds & 6.4 & 91.2 & 2.4 \\
\hline
\end{tabular}

Age is one of the basic biological characteristic of a person which is also an indicator which has an important bearing on the physical and psychological well being of women agricultural workers. Table 1 reveals that one third of the respondents (36 per cent) belong to the age group of 31- 40 years. There is close relation between the marital status and head of the family as 24 per cent are widows and 23.2 per cent are headed by women. The major reason behind widowhood in this village is due to severe alcoholism among men. Being a women and widow becomes the double burden for the respondents. Since Srivanjiyam is a Hindu pilgrimage centre with the existence of Srivanchinada swamy temple, majority of the respondents (99.2 per cent) are Hindus. The study reveals the rate of illiteracy among the respondents is 40 per cent.Among the respondents illiterate belong to the age of above 40 years where the younger respondents have at least attended primary or middle school education.

Majority of the households (64.0 per cent) are headed by the husband of the respondents which represents a patriarchal society though women contribute enormously for the social and economic well being of the family. Majority of them (97.2 per cent) live in own house which are predominantly thatched houses. More than half of the respondents ( 56.8 per cent) earn between Rs.2000 - 5000 with the main source of income as daily wages as agricultural worker and wages from MGNREGA.Majority of the respondents ( 68.0 per cent) have outstanding loan which they receive to meet out the family expenses, medical expenses and also to pay the previous loan.

In relating to the health of the respondents, majority of the respondents suffer with back pain, joint pain and leg pain which is mainly due to the continuous standing or bending posture in the field and the severe exposure to sun light causes head ache. Application of chemical fertilizers is also one of the major reasons for health issues and the table 2 reveals that 52.0 per cent of the respondents suffer with skin irritation which could be due to fertilizers and pesticides.

\section{CONCLUSION AND SUGGESTION:}

Women workers in agriculture comes under the purview of unorganised sector which lacks required welfare measures from the Government.Agricultural production is totally dependent on the contribution of women workers, though their work is not properly recognized. The socio economic condition of the agricultural women should be enhanced with systematic wage frame and by motivating them to get involved in political representation which would pave way for women empowerment. The health issues of them should be given required attention since their health is directly linked to the agricultural production. It is the need of the hour to consider the health issues of agricultural workers as public health and Government should periodically revise the existing health policies.

\section{ACKNOWLEDGEMENT:}

I kindly acknowledge the financial support provided by the Indian Council of Social Science Research for the Post Doctoral Fellowship and this paper has been prepared as a part of my ICSSR - PDF. (F.No.3-121/17-18/PDF). 
CONFLICT OF INTEREST: There is no conflict of interest.

\section{REFERENCE:}

1. http://censusindia. gov.in/201lcensus/dchb/3318_PART_B_DCHB_T HIRU V ARUR.pdf - Accessed on 25.01.2020

2. Ghosh, M., \& Ghosh, A. (2014). Analysis of women participation in Indian agriculture. IOSR J. Human. Soc. Sci, 19(5), 1-6.

3. Qadeer, I. (1997). Monica Das Gupta, Lincoln C. Chen and TN Krishnan (eds.), Women's Health in India: Risk and Vulnerability. Delhi: Oxford University Press, 1995.

4. Murty, S. (2008). Socio-economic participation of women in informal sector. RBSA Publishers.

5. Hawkes, C., \& Ruel, M. (2006). The links between agriculture and health: an intersectoral opportunity to improve the health and livelihoods of the poor. Bulletin of the World Health organization, 84, 984-990.

6. Raja Meenakshi, J and Sigamani, P (2020) "Menstrual practices and related Health issues among Women Agricultural workers - Thiruvarur district,Tamil Nadu"-unpublished document.

7. Ghosh, J. (2015). Unseen Workers: Women in Indian agriculture. The Frontline.

8. Raja Meenakshi. J (2016) "A study on psychosocial profile of Retired aged people". PhD Thesis

9. Tarar, M. A., Fatima, T., Salik, M. H., Akhtar, S., Khan, Y. N., Sultan, T, \& Yasmin, S. (2016). Health Problems Faced by Female Farm Workers in Rural Areas of Tehsil Dera Ghazi Khan: A Sociological Investigation. Journal of the Dow University of Health Sciences (JDUHS), 10(1). 